\title{
AESTHETIC PURPOSES IN THE USE OF THE POLICE POWER
}

IN THE recent case of State v. Brown, ${ }^{1}$ the North Carolina Supreme Court invalidated a state statute which required screening or fencing from public view any junk yard, trash, refuse, or garbage within one hundred and fifty feet of highways outside incorporated towns. ${ }^{2}$ The court held the statute unconstitutional on the ground that it was an exercise of the police power predicated solely on aesthetic considerations, without a substantial nexus to the public health, safety, morals, or welfare. ${ }^{3}$

This decision is supported by cases holding that similar statutes are unconstitutional when the intention of the legislature was basically aesthetic. ${ }^{4}$ These cases must be distinguished, however, from those which strike down ordinances because the required physical dimensions of the fence are inflexible and arbitrary and have no reference to the question of aesthetics. ${ }^{5}$ Moreover, the flat prohibition of all junk-yard

${ }^{2} 250$ N.C. 54 , 108 S.E.2d 74 (1959).

N.C. GEN. STAT. § $14-399$ (1953). Following the decision in this case, the legislature amended the statute to prohibit leaving any trash, refuse, garbage, or scrapped vehicles on the right of way of any state highway or public road outside incorporated towns, thus eliminating any reference to fencing or screening froin public view. N.C. GEN. STAT. § I4-399 (Supp. 1959).

${ }^{3}$ State v. Brown, 250 N.C. 54,59 , ro8 S.E.2d 74, 77-78 (1959). It seems that the motive of the North Carolina legislature was simply to keep land fronting on highways clean and attractive. The court acknowledged this in its opinion. Ibid.

'See Town of Vestal v. Bennett, r99 Misc. 4r, 104 N.Y.S.2d 830 (Sup. Ct. 1950), where the court noted that aesthetic considerations, even though a valid reason for the ordinance, were not so significant because the ordinance applied everywhere in the towneven to those places hidden from a highway. See also, Pfister v. Municipal Council of

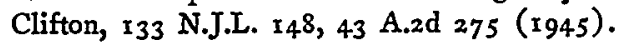

SThe case most relied upon by the court in the Brown decision was City of New Orleans v. Southern Auto Wreckers, Inc., I93 La. 895, I92 So. 523 (1939). The ordinance in that case required all junk yards to be surrounded by a "substantial feather-edged board fence" not less than seven feet high, and set up detailed specifications for its construction. The court said that a fencing requirement could be upheld as a safety ineasure, but that the particular specifications here were purely arbitrary. Id. at 906-07, 192 So. at 526-27.

See also Steiker v. Borough of East Paterson, $x_{37}$ N.J.L. 653, 6r A.2d 215 (1948), where the court could find no valid basis for a fence four to six inches high and for a one foot setback from property lines. In Vassallo v. Board of Comm'rs, 125 N.J.L. 4 r9, I5 A.2d 603 (r940), a fencing regulation was held arbitrary because directed only to automobile junk yards rather than junk yards generally.

In another case there was a dictuin to the effect that the fencing requirement had 
operations within a specific distance from a highway, whether or not they are screened from view, has not been sustained. ${ }^{6}$

When the courts wish to circumvent the rigid rule that aesthetic considerations are insufficient as the sole justification for junk-yard screening, and seek to support the legislature's expression of the public's growing sensitivity to obnoxious sights, statutory declarations of nuisance are considered and strained interpretations of the public health and safety are employed.

In common-law nuisance, mere unsightliness does not justify an injunction against junk-yard operations. ${ }^{7}$ Moreover, statutes declaring that junk yards are nuisances per se have been invalidated because such operations are not inherently harmful to the public. ${ }^{8}$ However, an ordinance which provided that a junk yard within a specified distance from a residential or commercial building was a nuisance has been sustained on the theory that the junk yard interfered with the community's comfortable enjoyment of its property. ${ }^{\circ}$

Those courts which have upheld fencing requirements have often seized upon some element of the public health or safety in order to support an exercise of the police power. This has occurred in cases where the legislature has required that the fence be a certain height in order to screen the yard from the public view. ${ }^{10}$ Aesthetic motives are expressly recognized, but the courts often reason that there is sufficient

unreasonable specifications. Upper Dublin Township v. Suriano, 68 Montg. Co. L.R. 326, 44 Mun. L.R. 108 ( $\mathrm{Pa}$. I952). The ordinance required that the junk yards be enclosed by "a tightly-built solid fence or wall constructed of brick, stone, concrete cement block or other similar matter or materials which shall be of a minimum height of six feet."

- Delawanna Iron \& Metal Co. v. Albrecht, 9 N.J. 424, 88 A.2d 616 (I952). Junk yards were prohibited in this case unless they were completely enclosed, and no part of the enclosure could be closer than 200 feet to the highway. The distance prohibition was invalidated, but in a dictum, the court admitted that the fencing requirement, standing alone, might be upheld. Cf., Township of Howell v. Sagorodny, 46 N.J. Super, 182, r 34 A.2d 452 (App. Div. I 957), where a distance prohibition was not invalidated, but the conviction was upheld under other sections of the ordinance.

${ }^{7}$ See, e.g., Feldstein v. Kammauf, 209 Md. 479, 121 A.2d $7 \times 6$ (1956).

8 "What is not an infringement upon public safety and is not a nuisance, cannot be made one by legislative fiat and then prohibited." Commonwealth v. Christopher, I84 Pa. Super. $205,210,132$ A.2d $7 \times 4,716$ (1957). Where an ordinance declared that automobile junk yards in plain view of a highway were a nuisance even thongh enclosed by a fence, the court held that it was based on purely arbitrary considerations. Vermont Salvage Corp. v. Village of St. Johnsbury, I I 3 Vt. 34I, 34 A.2d 188 (I943).

${ }^{\circ}$ Town of Grundy Center v. Marion, 23x Iowa 425, I N.W.2d 677 (1942). See also, State v. Kievman, 116 Conn. 458, I65 Atl. 601 (1933).

${ }^{10}$ City of Shreveport v. Brock, 230 La. 651, 89 So. 2d 156 (1956); Vermont Salvage Corp. v. Village of St. Johnsbury, II3 Vt. 34I, 34 A.2d 188 (I943). 
justification for the statute in the protection of passersby, or the elimination of an attractive nuisance. ${ }^{11}$

The most direct means of achieving purely aesthetic objectives in the regulation of junk yards has been to give local zoning authorities discretionary authority to withhold permits. Zoning boards may deny permits for the establishment of junk yards in certain locations in the absence of any legislative provision. For example, it is not unconstitutional to deny an application to establish an automobile junk yard on property which, though located in an industrial zone, is also on a main city thoroughfare and near a residential area. ${ }^{12}$

The courts have more readily accepted the aesthetic motivations of legislatures in other regulatory activities. ${ }^{13}$ These decisions represent a dynamic viewpoint and reflect changing social standards. ${ }^{14}$ The modern trend of judicial decision in the regulation of billboards, for instance, is to sanction aesthetic considerations as the sole justification for legislative regulation, even though there is some infringement of the rights of private property. ${ }^{15}$ Occasionally, the flat prohibition of all billboards has been upheld to preserve scenic beauty and historic sites. $^{16}$.Earlier decisions, however, regarded as constitutional only

${ }^{11}$ See cases cited note 10 supra; People v. Sevel, 120 Cal. App. Supp. 2d 907, 261 P.2d 359 (1953) (fire risks from gasoline fumes in tanks and greasy upholstery of secondhand automobiles); Chaiet v. City of East Orange, 136 N.J.L. 375, 56 A.2d 599 $(1948)$.

${ }_{13}$ "A motor vehicle junk yard is an eyesore. To locate one in close proximity to property used for residential purposes might reasonably be considered something approaching a public nuisance." Miller v. Zoning Bd. of App., I $_{3} 8$ Conn. 6Io, 6I4, 87 A.2d 808, 8 10 (1952). See also, Delmar v. Planning \& Zoning Bd., 19 Conn. Supp. 2I, 109 A.2d 604 (C.P. 1954).

${ }^{13}$ MCQuillin, 8 MUNiCipal Corporations $\$ 25.3$ I (1957); RhXNe, MUNicipal LAW \$§ 26-4, 32-24 (1957); YOKLEY, I ZONING LAW AND PRACTICE § 17.I (Supp. 1958); Dukeminier, Zoning for Aesthetic Objectives: A Reappraisal, 20 LaW \& CoNTEMP. ProB. 218 (1955); Rodda, The Accomplishment of Aesthetic Purposes Under the Police Power, 27 So. Cax. L. Rev. 149 (1954).

${ }^{14}$ State ex rel. Carter v. Harper, 182 Wis. 148,196 N.W. $45 \times$ (1923). The Supreme Court has said that zoning laws enacted under the police power are subject to gradual change to meet changes in community life. Village of Euclid v. Ambler Realty Co., 272 U.S. $365,386-89$ (1926).

${ }^{15}$ Murphy, Inc. v. Town of Westport, I3 1 Conn. 292, 40 A.2d 177 (1944); General Outdoor Advtg. Co. v. Department of Pub. Works, 289 Mass. 149, 193 N.E. 799 (1935), appeal dismissed, 297 U.S. 725 (1936); Churchill v. Rafferty, 32 P.I. 580 (1915), appeal dismissed, 248 U.S. 59 (1918); Commonwealth v. Trimmer, 53 Dauph. Co. 91, 34 Mun. L.R. 37 (Pa. 1942); Preferred Tires, Inc. v. Hempstead, I70 Misc. 1017, 19 N.Y.S.2d 374 (Sup. Ct. 1940). See RHXNE, op. cit. supra note 13 $_{3}$, at $\S 32-$ 55.

${ }^{16}$ City of New Orleans v. Levy, 223 La. 14, 64 So. 2d 798 (1953); City of New 
those regulations which were premised on the promotion of the public health and safety. ${ }^{17}$ The courts now admit that even when the legislature imposes rigid physical restrictions on the size of the billboards for the general health and safety, the obnoxious effects of the presence of billboards in residential sections and their blighting effects in industrial districts are not entirely abated..$^{18}$

The leading Supreme Court case of Berman v. Parker ${ }^{10}$ epitomizes the liberal trend of judicial decision. In that case the Court did not distinguish the applicability of the police power and the power of eminent domain, ${ }^{20}$ and it appears settled that either or both of these powers may be used to support legislative policies premised exclusively upon aesthetic considerations under a liberal conception of what constitutes the public welfare. ${ }^{21}$

Orleans v. Pergament, r98 La. 852, 5 So. 2d 129 (194x). See also, Opinion of the Justices to the Senate, 333 Mass. 773, 128 N.E.2d 557 (1955).

${ }^{17}$ See, e.g., General Outdoor Advtg. Co. v. Indianapolis, 202 Ind. 85, 172 N.E. 309 (1930). A trend toward upholding regulations on aesthetic grounds was noted in this case, but the court said it could not approve a general prohibition under existing law. See RHYNe, op. cit. supra note 13 , at 533-35; Note, 23 GEO. WASH. L. REv. 730, 73843. (1955).

${ }^{18}$ Grant v. Mayor of Baltimore, 212 Md. 301, 129 A.2d 363 (1957). Moreover, the size of billboards may now be regulated on purely aesthetic grounds under a general welfare concept. Merritt v. Peters, 65 So. 2d 861 (Fla. 1953). Cf., City of Miami Beach v. Ocean \& Inland Co., 147 Fla. 480,3 So. 2d 364 (1941). See Note, 29 N.Y.U.L. REv. 1017 (1954).

10348 U.S. 26 (1954).

${ }^{20}$ See Note, 23 GEO. WASH. L. REv. 730 (1955).

${ }^{21}$ Mr. Justice Douglas wrote the opinion, saying: "Public safety, public health, morality, peace and quiet, law and order-these are some of the more conspicuous examples of the traditional application of the police power to municipal affairs. Yet they merely illustrate the scope of the power and do not delimit it. . . . The concept of public welfare is broad and inclusive. ... The values it represents are spiritual as well as physical, aesthetic as well as monetary. It is within the power of the legislature to determine that the community should be beautiful as well as healthy, spacious as well as clean, well-balanced as well as carefully patrolled." 348 U.S. at 32.

Compare the words of Justice Douglas with those of Chief Justice Clarke of the North Carolina Supreme Court, writing in 1924, in a case cited in the Brown decision. In regard to the fact that aesthetics were becoming a motive for the use of police power, he said: "This expresses the uniform trend of legislation in regard to municipalities which are coming to be viewed not only as instrumentalities for the enforcement of law and order, but for the abolition of unsightly places and sounds and for the enhancement not only of the physical conveniences such as lights, water and sewerage, but for the preservation and improvement of the surroundings that will be pleasing to the eye and make the city more desirable as a place of residence ... though a regulation for the latter purpose alone cannot be sustained except upon compensation under the right of eminent domain." Turner v. City of New Bern, 187 N.C. $54 x, 543-44,122$ S.E. 469, 471 (1924).

The Berman case has been relied upon frequently by the state courts in upholding 
The role of aesthetics has long been accepted in land-use ordinances. A business may be excluded from a residential district to avoid the creation of "eyesores,"22 and it is not improper for a zoning ordinance to require prior approval of plans for proposed structures by a building board, whose sole criterion is exterior architectural appeal. ${ }^{23}$ The restriction of land use to single-family dwellings is also a proper expression of the desire to maintain the residential character of an area. ${ }^{24} \mathrm{~A}$ zoning ordinance may also establish minimum dwelling dimensions and locations within the residential district under a theory of serving community welfare by creating a desirable place in which to live. ${ }^{25}$

Traditionally, the authority for statutes and ordinances has been the states police power to promote the public safety, health, morals, or general welfare. ${ }^{26}$ The modern concept of "general welfare" now also includes aesthetics. ${ }^{27}$ Prior decisions were to the effect that aesthetics could be only a subordinate consideration in framing legislative regulations. Today, however, community development demands the frank recognition of aesthetics as a primary criterion, and recent decisions uphold this view. Since there has been a liberal use of aesthetics as a

slum clearance programs. See, e.g., Bowker v. City of Worcester, 334 Mass. 422, 136 N.E.2d 208 (1956). See 2 YokLEY, op. cit. supra note 13 , § 199.1.

22 'If by the term 'aesthetic considerations' is meant a regard merely for outward appearances, for good taste in the matter of the beauty of the neighborhood itself, we do not observe any substantial reason for saying that such a consideration is not a matter of general welfare. The beauty of a fashionable residence neighborhood in a city is for the comfort and happiness of the residents, and it sustains in a general way the value of property in the neighborhood. It is therefore as much a matter of general welfare as is any other condition that fosters comfort or happiness, and consequent values generally of the property in the neighborhood." State ex rel. Civello v. City of New Orleans, 154 La. 271, 284, 97 So. 440, 444 (1923). See also Pierro v. Baxendale, 20 N.J. 17, I18 A.2d 401 (1955), where motels were excluded to preserve the beauty of a residential community.

${ }^{23}$ State ex rel. Saveland Park Holding Corp. v. Wieland, 269 Wis. 262, 69 N.W.2d 217 (1955), cert. denied, 350 U.S. 841 (1955).

${ }^{23}$ Elbert v. Village of North Hills, 28 N.Y.S.2d 317 (Sup. Ct. 1941); Best v. Zoning Bd. of Adjustment, $393 \mathrm{~Pa}$. 106, I41 A.2d 606 (1958).

${ }^{25}$ Lionshead Lake, Inc. v. Wayne Township, 1o N.J. 165, 89 A.2d 693 (I952), appeal dismissed, 344 U.S. 9 19 (1953).

${ }^{26}$ Chicago, B. \& Q. Ry. v. State of IIl. ex rel. Drainage Comm'rs, 200 U.S. 561,592 (1906).

${ }^{27}$ As Justice Holmes said in Noble State Bank v. Haskell, 219 U.S. 104, I I I (1911): "It may be said in a general way that the police power extends to all the great public needs. . . . It may be put forth in aid of what is sanctioned by usage, or held by the prevailing morality or strong and preponderant opinion to be greatly and immediately necessary to the public welfare." See also, Sayre, Aesthetics and Property Values: Does Zoning Promote the Public Welfare?, 35 A.B.A.J. 471 (1949). 
standard in other areas of municipal law, it now seems desirable to employ it in the area of junk-yard activity as well.

In the instant decision, the North Carolina court expressed tacit agreement with the objectives of the state legislature, but could find no authority which it felt sustained the statute. By virtue of this decision, the court has failed to take advantage of an opportunity to align North Carolina with that concept of the general welfare which holds that aesthetic considerations sanction the use of the police power. 